\title{
PEMBERDAYAAN PETERNAK MELALUI BIMBINGAN TEKNIS SELEKSI BIBIT SAPI BALI PADA KAWASAN SENTRA BIBIT SAPI BALI DI KABUPATEN KONAWE SELATAN
}

\author{
La Ode Nafiu ${ }^{1}$, Achmad Slamet Aku², Musram Abadi ${ }^{3}$, Deki Zulkarnain ${ }^{4}$ \\ ${ }^{1,2,3,4}$ Fakultas Peternakan Universitas Halu Oleo, Kendari \\ e-mail 1dnafiu@uho.ac.id
}

\begin{abstract}
ABSTRAK
Populasi sapi Bali di Kabupaten Konawe Selatan tahun 2017 berjumlah 67.746 ekor (BPS Konawe Selatan, 2018) atau sekitar $18,27 \%$ dari total 370.772 ekor dan merupakan daerah dengan populasi sapi potong tertinggi di Sulawesi Tenggara (BPS Sulawesi Tenggara, 2018). Berdasarkan hasil identifikasi permasalahan yang ditemukan oleh tim pelaksana, maka disepakati beberapa permasalahan prioritas untuk dilakukan perbaikan sebagai berikut: Kurangnya pengetahuan dan pemahaman peternak tentang konsep seleksi ternak bibit; Kurangnya pengetahuan dan keterampilan peternak dalam memilih ternak bibit jantan maupun betina berdasarkan sifat kuantitatifnya serta memenuhi standar baku mutu yang baik; Kurangnya pengetahuan dan keterampilan peternak mengenai tatalaksana pemeliharaan ternak bibit; dan Kurangnya pengetahuan dan pemahaman peternak terhadap manajemen pemberian pakan ternak bibit. Adapun hasil kegiatan yang terlaksana di Desa Wonua Morini Kecamatan Palangga Kabupaten Konawe Selatan meliputi: Penyuluhan potensi pengembangan dan konsep seleksi serta tatalaksana pemeliharaan ternak bibit sapi Bali mampu meningkatkan pengetahuan peternak dalam mengembangan usaha ternak sapi Bali; Bimbingan teknis metode seleksi dan penamaman hijauan pakan unggul serta pengawetan hijauan pakan ternak mampu menambah keterampilan peternak dalam memanfaatkan sumber-sumber pakan konsetrat lokal; Bimbingan teknis pemanfaatan sumber pakan konsentrat lokal sebagai pakan penguat seperti ampas sagu dan ampas tahu telah dimanfaatkan.
\end{abstract}

Kata kunci : Sapi Bali, pemuliaan, seleksi.

\begin{abstract}
The cattle population on Bali in South Konawe Regency was 67,746 in 2017 (South Konawe BPS, 2018) or around $18.27 \%$ of the total of 370,772 and is the area with the highest cattle population in Southeast Sulawesi (BPS Southeast Sulawesi, 2018). Based on the results of the identification of the problems identified by the team for the implementation of the activities and subsequently discussed together with the breeding community, it was agreed that various priority problems should be improved as follows: lack of knowledge and understanding of the Breeders on the concept of selection of breeding animals; lack of knowledge and skills of breeders in the selection of male and female breeders due to their quantitative character and compliance with good quality standards; lack of knowledge and skills of breeders in the management of breeding animals; and lack of knowledge and understanding of breeders in managing animal feed. Results of activities in Wonua Morini Village, Palangga District, Konawe Selatan District include: Advising on the potential development and concept of selecting and managing the maintenance of Bali cattle breeding, on the knowledge of the breeders about the development of the Bali cattle business to expand; Technical guidance on the selection and addition of superior feed and animal feed preservation can improve farmers' skills in using local sources of concentrate. Technical guidelines on the use of local concentrate feed sources as reinforcing feed such as sago pulp and tofu waste have been used by.
\end{abstract}


Key words: Bali cattle, breeding, selection

\section{PENDAHULUAN}

Populasi sapi Bali di Kabupaten Konawe Selatan tahun 2017 berjumlah 67.746 ekor (BPS Konawe Selatan, 2018) atau sekitar 18,27\% dari total 370.772 ekor dan merupakan daerah dengan populasi sapi potong tertinggi di Sulawesi Tenggara (BPS Sulawesi Tenggara, 2018). Pengembangan sapi di Konawe Selatan didukung oleh banyak faktor, diantaranya: (1) animo masyarakat memelihara sapi pedaging sangat tinggi, (2) areal pertanian tanaman pangan dan perkebunan yang dapat diintegrasikan dengan ternak sapi cukup luas, (3) tersedia areal penggembalaan yang cukup luas, dan (4) kawasan hutan sangat luas yang sebagian diantaranya terdapat padang rumput dan dapat dikonversi menjadi padang pengggembalaan (Nafiu dkk., 2017 a ; Nafiu dkk., 2017b). Peningkatan produksi sapi Bali di Sulawesi Tenggara, termasuk di Konawe Selatan dilakukan dengan dua pendekatan, yaitu: (1) peningkatan populasi, dan (2) peningkatan produktivitas per ekor. Peningkatan populasi antara lain ditempuh melalui: (a) peningkatan skala usaha, (b) perluasan wilayah penyebaran, dan (c) peningkatan kapasitas tampung wilayah. Sementara itu pendekatan peningkatan produktivitas per ekor sapi diantaranya ditempuh melalui: (a) perbaikan mutu genetik, (b) perbaikan pakan, dan (c) perbaikan manajemen pemeliharaan (Nafiu, 2018).

Pemerintah Kabupaten Konawe Selatan telah menjadikan sapi Bali sebagai program utama daerah pada subsektor peternakan. Sementara itu Pemerintah Pusat melalui Kementrian Pertanian dalam rangka peningkatan ketersediaan bibit sapi (bakalan) telah menetapkan Kabupaten Konawe Selatan sebagai salah satu daerah sentra perbibitan sapi Bali di Indonesia. Sentra perbibitan sapi Bali tersebut tersebar pada empat wilayah kecamatan diantaranya Kecamatan Palangga, Tinanggea, Buke dan Kecamatan Baito (Kepmentan, 2016).

Kualitas dan ketersediaan sapi bibit akan menentukan keberhasilan peningkatan produksi. Nafiu dkk (2018) melaporkan bahwa permasalahan utama yang dihadapi dalam pengembangan sapi Bali di Kabupaten Konawe Selatan adalah performan sapi Bali yang masih relatif rendah. Salah satu penyebabnya adalah rendahnya pengetahuan dan keterampilan peternak tentang seleksi dan implementasinya dan pembibitan sapi Bali. 
Permasalahan yang berhubungan dengan sistem seleksi bibit sapi Bali yang tidak terkontrol berimbas pada lambatnya pertumbuhan dan penurunan kualitas produksi. Kebanyakan pejantan unggul dijual cepat oleh peternak karena memiliki harga jual yang tinggi atau karena alasan desakan ekonomi. Selain itu, penanganan dan pencegahan penyakit reproduksi masih dilakukan secara tradisional. Berdasarkan hasil identifikasi permasalahan yang ditemukan oleh tim pelaksana kegiatan kemudian dibahas bersama dengan masyarakat peternak, maka disepakati beberapa permasalahan prioritas untuk dilakukan perbaikan sebagai berikut: (1) Kurangnya pengetahuan dan pemahaman peternak tentang konsep seleksi ternak bibit; (2) Kurangnya pengetahuan dan keterampilan peternak dalam memilih ternak bibit jantan maupun betina berdasarkan sifat kuantitatifnya serta memenuhi standar baku mutu yang baik; (3) Kurangnya pengetahuan dan keterampilan peternak mengenai tatalaksana pemeliharaan ternak bibit;

(4) Kurangnya pengetahuan dan pemahaman peternak terhadap manajemen pemberian pakan ternak bibit.

Berdasarkan uraian tersebut, maka tim pelaksana kegiatan PKM mengembangkan metode seleksi pembibitan sapi Bali melalui kegiatan "Bimbingan Teknis Seleksi Bibit Sapi Bali pada Kawasan Sentra Bibit Sapi Bali di Kabupaten Konawe Selatan". Kegiatan pengabdian ini diharapkan mampu meningkatkan dan mengembangkan pengetahuan dan keterampilan peternak dalam hal seleksi pada wilayah sentra bibit sapi Bali.

\section{METODE}

Metode pelaksanaan yang diterapkan untuk pencapaian target pelaksanaan kegiatan PKM bimbingan teknis seleksi bibit sapi Bali di Kabupaten Konawe Selatan dilaksanakan dengan dua metode kegiatan yaitu: Sosialisasi atau penyuluhan dan Bimbingan Teknis serta Introduksi Teknologi Tepat Guna yang terbagi dalam beberapa tahapan diantaranya yaitu:

1. Tahap I : Kunjungan dan identifikasi kendala dan hambatan serta potensi dan peluang sehingga menjadi dasar permasalahan dan solusi yang akan ditawarkan.

2. Tahap II: Sosialisasi dan Penyuluhan

Kegiatan yang ditawarkan dalam kegiatan ini berupa transfer pengetahuan yang dimiliki oleh tim pelaksana kegiatan mengenai hal-hal yang berkaitan dengan sapi Bali, peranan seleksi dalam meningkatkan mutu genetik yang pada akhirnya meningkatkan produktivitas ternak. Adapun materi penyuluhan yang ditawarkan meliputi: 
a. Penyuluhan potensi sapi Bali dan peranannya dalam swasembada daging dan peningkatan kesejahteraan peternak.

b. Penyuluhan tentang konsep seleksi dan metode seleksi untuk meningkatkan mutu genetik ternak sapi Bali.

c. Penyuluhan tentang krieria seleksi sapi bibit jantan dan betina berdasarkan sifat kualitatitif dan kuantitatif yang memenuhi SNI bibit sapi Bali.

3. Tahap III : Bimbingan teknis

Peningkatan keterampilan teknis anggota mitra dilakukan melalui pelibatan mereka dalam pelatihan dan demonstrasi selama kegiatan bimbingan teknis berlangsung, berupa:

a. Bimbingan teknis aplikasi seleksi untuk memilih bibit sapi Bali jantan dan betina.

b. Bimbingan teknis sistem dan model mengembangbiakkan (breeding) ternak bibit sapi Bali hasil seleksi.

c. Bimbingan teknis penamaman hijauan pakan unggul.

d. Bimbingan teknis pengawetan hijauan pakan ternak dan pemanfaatan limbah pertanian.

\section{PEMBAHASAN}

\section{Sosialisasi dan Penyuluhan}

Dalam mengembangkan ternak sapi potong tentunya tidak terlepas dari peranan kelompok tani ternak dalam mengupayakan ternaknya agar mendapat nilai tambah serta efisien dalam pengelolaannya. Upaya yang perlu dikembangkan dalam membina dan memantapkan kelompok peternak adalah memperkuat kelembagaan ekonomi petani/peternak di pedesaan, untuk itu diperlukan pendekatan yang efektif agar petani/peternak dapat memanfaatkan program pembangunan yang ada, secara berkelanjutan, melalui pertumbuhan rasa memiliki, partisipasi dan pengembangan kreatifitas, disertai dukungan masyarakat lainnya sehingga dapat berkembang dan dikembangkan oleh masyarakat tani disekitarnya (Muslim, 2006).

Program Kemitraan Masyarakat (PKM) yang dilakukan melalui pengabdian bertujuan memberikan suatu contoh atau model pengembangan usaha peternakan melalui proses penyuluhan dan 
bimbingan teknis secara tepat dan mengidentifikasi kendala dan hambatan serta peluang dan kekuatan kelompok peternak baik secara internal maupun eksternal (Abadi, M., 2019). Tujuan penyuluhan adalah merubah prilaku manusia kearah yang lebih maju. Apabila telah dapat merubah sikap manusia berarti dia telah berhasil merubah pengetahuan, kecakapan dan dapat menumbuhkan kesadaran dari diri manusia itu sendiri. Proses Sosialisasi dan bimbingan teknis disajikan pada Gambar 1.
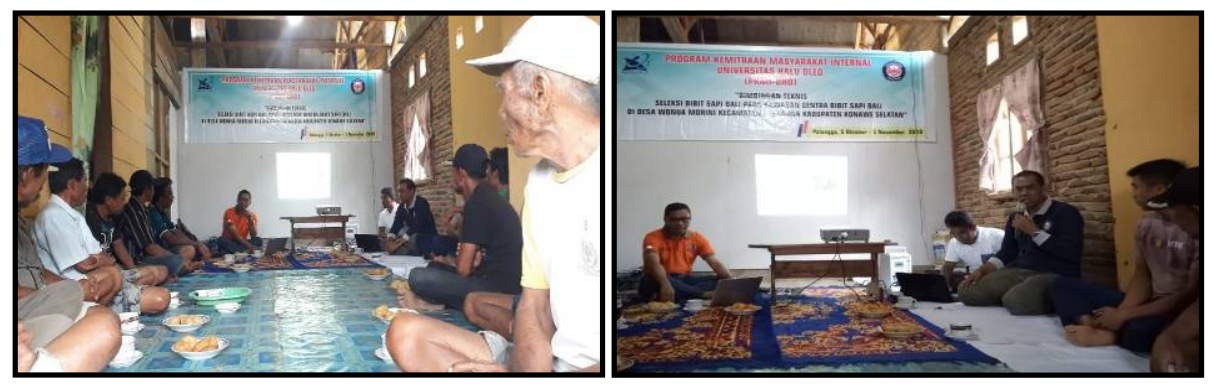

Gambar 1. Penyuluhan Kepada Peternak Terkait Seleksi Ternak Sapi Bali

Kegiatan ini dapat meningkatkan pengetahuan dan keterampilan petani untuk merubah perilaku, penyuluh pertanian menyiapkan berbagai macam metode penyuluhan seperti demonstrasi yang mampu mendorong kesadaran peternak tentang pentingnya memiliki pengetahuan baru dalam mengelola usaha ternaknya. Produktivitas peternak dapat ditingkatkan dengan cara mengoptimalkan pengetahuan peternak. Tingkat pengetahuan peternak dapat ditingkatkan dengan metode komunikasi. Disini peran penyuluh lapangan sangat diperlukan dalam upaya transfer teknologi kepada peternak mengenai manajemen ternak itik yang tepat (Abdullah, 2008).

\section{Bimbingan Teknis Seleksi Untuk Memilik Bibit Sapi Bali Jantan dan Betina}

Seleksi dalam pemuliaan selalu dikaitkan dengan penentuan apakah seekor hewan dapat atau diperbolehkan menghasilkan sejumlah keturunan. Penentuan tersebut ditentukan oleh alam (seleksi alam) atau oleh peternak dalam seleksi buatan, atas dasar suatu sifat atau dugaan mengenai mutu genetik seekor hewan. Kebijakan pengembangan sapi bakalan antara lain bertujuan untuk menghindari terjadinya pengurasan bibit sapi lokal, mencegah persilangan acak yang tidak terprogram, dan menghindari ketergantungan pada impor sapi di masa mendatang. Apabila Indonesia telah memiliki commercial breed yang produktif, maka usaha perbibitan nasional akan lebih berkembang karena menguntungkan para pelaku perbibitan berskala besar (Rasali, dkk., 2014).

Kebijakan perbibitan dan pemuliabiakan sapi nasional ditujukan pada dua hal penting, yaitu pemurnian sapi lokal asli Indonesia (seperti sapi Bali, Madura, Peranakan Ongole, Sumba Ongole) untuk 
sumber bibit unggul dan penggemukan. Terkait dengan hal itu, beberapa alternatif program perbibitan nasional perlu dilakukan, antara lain:1) perluasan padang pangonan melalui integrasi tanaman-ternak, 2) perubahan peraturan perundangan tentang kewenangan pemerintah pusat terkait dengan pengaturan mutu genetik ternak, pelestarian kawasan sapi lokal, dan kewenangan Komisi Nasional Plasma Nutfah, 3) revitalisasi peran Balai Pembibitan Ternak Unggul dengan menghidupkan kembali "ladang ternak", dan 4) penelitian dampak persilangan terhadap produktivitas ternak dan sumbangan ekonominya (Hardjosubroto, 2004).

Metode seleksi yang digunakan dalam program ini adalah metode Seleksi penyingkiran secara bebas. Metode seleksi penyingkiran secara bebas merupakan seleksi dilakukan terhadap beberapa sifat yang dianggap mempunyai nilai ekonomis secara bersamaan. Setiap hewan yang tidak dapat mencapai syarat minimal tersebut disingkirkan. Metode pengukuran tubuh sapi Bali yang dilakukan oleh TIM PKMI disajikan pada Gambar 2.
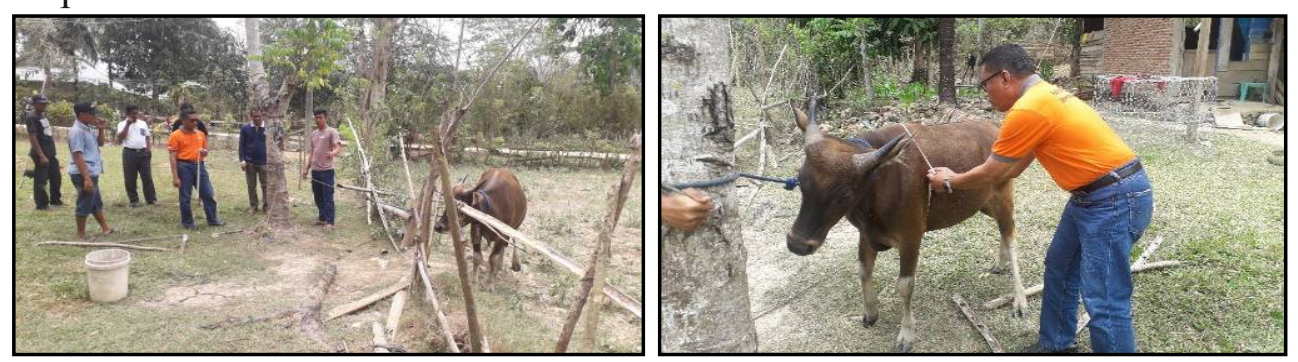

Gambar 2. Metode Pengukuran Tubuh Ternak Sapi Bali

Dalam pengukuran sifat kuantitatif ternak sapi potong dilakukan pengukuran terhadap tubuh ternak. Metode pengukuran dilakukan dengan cara sebagai berikut:

a. Bobot badan (BB): diperoleh dengan cara penimbangan yang dilakukan sebelum sapi diberi makan atau digembalakan dengan menggunakan timbangan $(\mathrm{kg})$.

b. Panjang badan (PB): jarak garis lurus dari tepi depan luar tulang scapula sampai dengan benjolan tulang tapis (osischium), diukur dengan tongkat ukur (cm).

c. Lingkar dada (LD): diukur melingkar rongga dada dibelakang sendi tulang bahu (osscapula) diukur dengan pita ukur (cm).

d. Tinggi Pundak (TP): jarak tertinggi pundak sampai tanah, diukur dengan tongkat ukur (cm).

e. Tinggi Pinggul (TP): jarak tertinggi pinggul sampai tanah, diukur dengan tongkat ukur (cm). Lebih jelasnya ukuran-ukuran tubuh yang diamati.

Penanaman Rumput Unggul (Rumput Odod) 
Keberhasilan produksi suatu peternakan sangat tergantung kepada kualitas pakan, oleh karena itu ketersediaan hijauan pakan sepanjang masa dan memilih hijauan yang berkualitas unggul adalah sangat penting. Usaha untuk meningkatkan konsumsi protein hewani tidak dapat dilepaskan dari usaha untuk meningkatkan produksi dan mutu hijauan pakan (Prawiradiputra dkk, 2006). Pemberian pakan yang berkualitas baik, diharapkan dapat memberikan penampilan produksi yang baik bagi ternak yang mengkonsumsinya. Peningkatan produksi terutama daging dan susu sangat tergantung pada kualitas dan kuantitas hijauan pakan. Dengan demikian dapat dinyatakan bahwa segala usaha untuk meningkatkan konsumsi protein hewani tidak bisa dilepaskan dari usaha meningkatkan produksi dan mutu hijauan pakan (Prawiradiputra dkk, 2006).

Hijauan merupakan makanan utama bagi ternak ruminansia dan berfungsi tidak hanya sebagai pengenyang tetapi juga berfungsi sebagai sumber nutrisi, yaitu protein, energi, vitamin dan mineral. Hijauan yang bernilai gizi tinggi cukup memegang peranan penting karena dapat menyumbangkan zat pakan yang lebih ekonomis dan berhasil guna bagi ternak (Herlinae, 2003). Prosesi penanaman hijauan makanan ternak pada kebun percontohan disajikan pada Gambar 3.
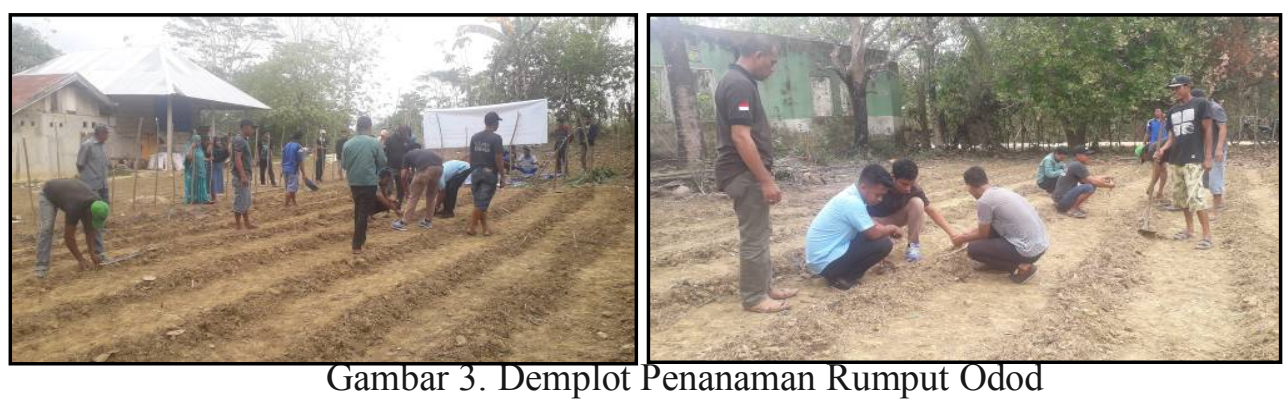

Keuntungan utama dari hijauan sebagai makanan ternak ruminansia adalah suatu pakan yang mudah didapat pada berbagai keadaan, sedangkan kelemahannya adalah tidak tersedia secara berkelanjutan terutama pada musim kemarau (Herlinae, 2003). Sementara itu, berdasarkan hasil penelitian Budiasa (2005) bahwa produksi hijauan pakan ternak sebagai sumber pakan ternak ruminansia sangat dipengaruhi oleh penggunaan lahan dan topografi.

\section{Teknis Pengawetan Hijauan Pakan Segar Ternak (Silase)}

Pengaruh iklim sangat menentukan ketersediaan hijauan sebagai pakan. Pada musim penghujan produksi hijauan berlimpah dan sebaliknya di musim kering atau kemarau hijauan sebagai sumber pakan menjadi berkurang. Untuk mengatasi hal tersebut biasanya petani peternak memberi pakan sisa-sisa 
pertanian seperti jerami. Ketersediaan hijauan secara kuantitas dan kualitas juga dipengaruhi oleh pembatasan lahan tanaman pakan karena penggunaan lahan untuk tanaman pakan masih bersaing dengan tanaman pangan. Kebutuhan hewan ternak ruminansia yang semakin tinggi, memaksa peternak harus lebih inovatif dalam pemberian pakan hijauan pada hewan ternak, guna mengantisipasi jika musim kering datang dan pakan hijauan akan semakin sulit ditemukan, maka peternak memerlukan cara penyimpanan bahan pakan segar atau bahan pakan simpan dalam kurun waktu tertentu. Hal ini dapat dilakukan dengan pengawetan basah (silase) maupun penawetan kering (hay), sehingga kesulitan mencari bahan pakan saat musim kering sudah tidak lagi menjadi kendala bagi peternak (Yulianto dan Suprianto, 2010).

Pembuatan silase ransum lengkap selain untuk pengawetan juga dimaksudkan agar bahan baku pasca panen yang berkadar air tinggi langsung dapat digunakan, sehingga secara aplikatif teknologi ini dapat memotong jalur produksi pakan menjadi lebih singkat (Allaily dkk., 2011). Proses pembuatan silase disajikan pada Gambar 4.
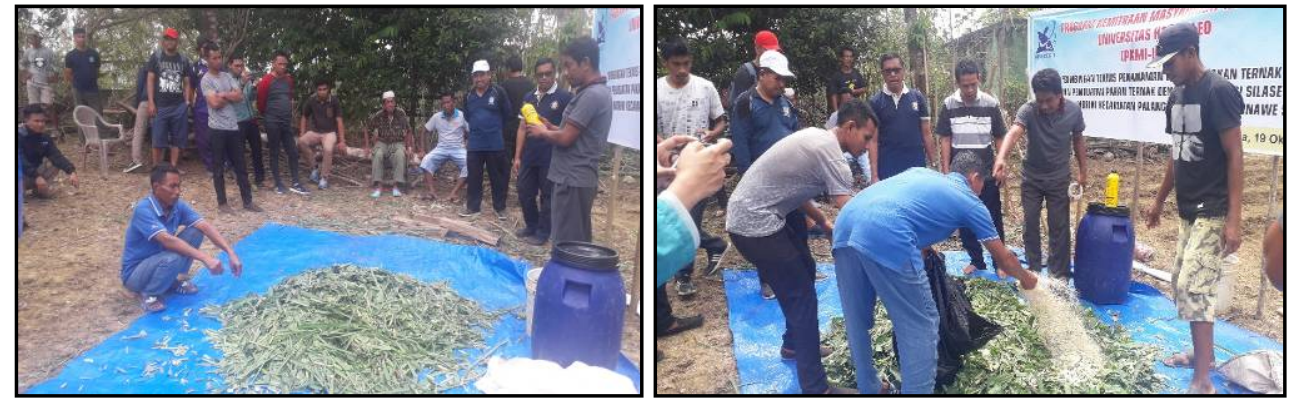

Gambar 4. Demonstrasi Pembuatan Silase

Silase dapat diartikan sebagai bahan pakan ternak hijauan segar yang disimpan dalam satu tempat kedap udara (tanpa udara). Silase ini dapat dibuat dari berbagai macam hijauan segar berserat tinggi maupun limbah pertanian (Rukmana, 2001). Silase merupakan awetan basah hijauan pakan ternak dan yang paling ideal digunakan adalah sebangsa rumput-rumputan karena merupakan bahan ternak yang mengandung serat tinggi, komposisi kimia yang memadai untuk dapat diawetkan melalui proses fermentasi. Fermentasi dapat meningkatkan kualitas nutrisi bahan pakan, karena pada proses fermentasi terjadi perubahan kimiawi senyawa organik 7 (karbohidrat, lemak, protein, serat kasar dan bahan organik lain) baik dalam keadaan aerob maupun anaerob, melalui kerja enzim yang dihasilkan mikroba. Selain itu pembuatannya tidak bergantung pada musim (Hapsari dkk., 2014).

Teknis Fermentasi Pakan Konsentrat Lokal (Ampas Sagu) 
Pakan merupakan faktor terpenting dalam meningkatkan produktivitas ternak. Perhitungan faktor ekonomis juga menjadi perhitungan bagi peternak dalam pemilihan komponen pakan. Pemanfaatan tanaman lokal diharapkan mampu mengurangi proporsi biaya pakan.

Ketersediaan dan kualitas pakan masih menjadi masalah krusial pada peternakan di Indonesia pada umumnya dan khususnya di Palangga, Konawe Selatan. Potensi bahan baku lokal berupa limbah ampas sagu sangat melimpah, namun sampai saat ini pemanfaatannya belum optimal, hanya dibiarkan menumpuk pada tempat-tempat pengolahan tepung sagu sehingga menyebabkan pencemaran lingkungan. Salah satu solusi yang dapat diterapkan adalah pengembangan pakan alternatif yang diupayakan dengan pemanfaatan limbah industri sebagai bahan pakan lokal yaitu ampas sagu. Demonstrasi pembuatan pakan menggunakan limbah ampas sagu di jadikan pada gambar 5.
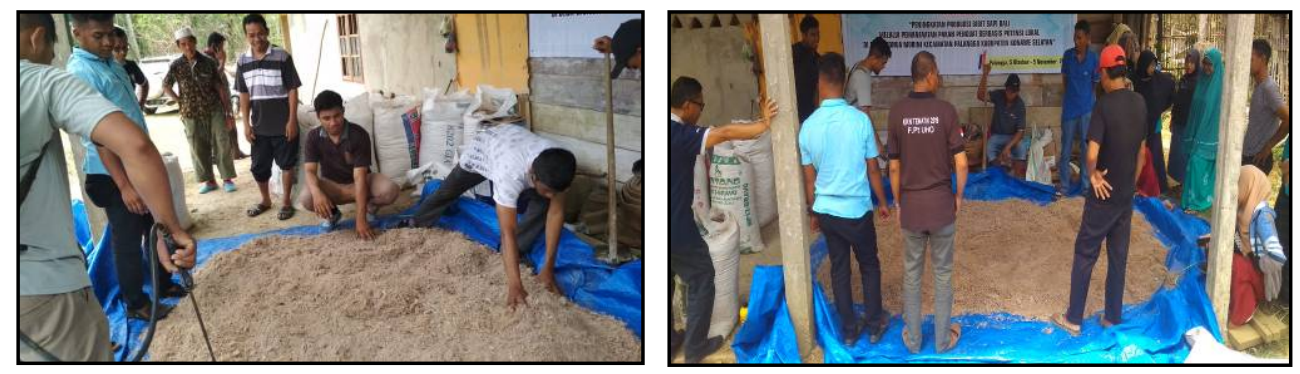

Gambar 5. Fermentasi Pakan Konsentrat Lokal (Ampas Sagu dan Ampas Tahu)

Kiat (2006), melaporkan bahwa limbah sagu mengandung komponen penting seperti pati dan selulosa. Jumlah limbah kulit batang sagu mendekati 26\%, sedangkan ampas sagu sekitar 14\% dari total bobot balak sagu. Ampas mengandung 65,7\% pati dan dan sisanya merupakan serat kasar, protein kasar, lemak, dan abu. Dari persentase tersebut ampas mengandung residu lignin sebesar 21\%, sedangkan kandungan selulosa di dalamnya sebesar 20\% dan sisanya merupakan zat ekstraktif dan abu. Di sisi lain, kulit batang sagu mengandung selulosa (57\%) dan lignin yang lebih banyak (38\%) daripada ampas sagu.

Salah satu kendala belum optimalnya pemanfaatan limbah sagu tersebut karena lemahnya pengetahuan teknis masyarakat petani mengenai potensi nilai ekonomis limbah ampas sagu. Perlunya penyeliaan dan transfer teknologi bagaimana proses mengupayakan limbah ampas sagu yang berlimpah menjadi bahan dasar pakan ternak yang memiliki nilai ekonomis tinggi. Perlunya pelatihan mengenai penatalaksanaan pengelolaan usaha pengolahan limbah ampas sagu sebagai bahan dasar pakan ternak unggas dan ruminansia. Perlunya pemberian pendampingan untuk menyelesaikan permasalah tersebut sebagai tujuan dalam pelaksanaan kegiatan pemberdayaan masyarakat melalui Program PKM-I ini. 


\section{SIMPULAN}

Pelaksanaan kegiatan Pengabdian Kepada Masyarakat (PKM) Internal dilakukan dengan berbagai program yang bertujuan meningkatkan dan mengembangkan pengetahuan dan keterampilan peternak tentang seleksi bibit sapi Bali pada kawasan sentra bibit sapi Bali di Kabupaten Konawe Selatan dan pemanfaatan hijuan pakan ternak dan sumber pakan konsentrat lokal yang berkualitas. Berdasarkan hal tersebut maka ditarik kesimpulan sebagai berikut:

1. Penyuluhan potensi pengembangan dan konsep seleksi serta tatalaksana pemeliharaan ternak bibit sapi Bali mampu meningkatkan pengetahuan peternak dalam mengembangan usaha ternak sapi Bali di Desa Wonua Morini Kecamatan Palangga Kabupaten Konawe Selatan.

2. Bimbingan teknis metode seleksi dan penamaman hijauan pakan unggul serta pengawetan hijauan pakan ternak mampu menambah keterampilan peternak dalam memanfaatkan sumber-sumber pakan konsetrat lokal yang terdapat di sekitar Desa Wonua Morini Kecamatan Palangga Kabupaten Konawe Selatan.

3. Bimbingan teknis pemanfaatan sumber pakan konsentrat lokal sebagai pakan penguat seperti ampas sagu dan ampas tahu telah dimanfaatkan oleh peternak di Desa Wonua Morini Kecamatan Palangga Kabupaten Konawe Selatan.

Dalam rangka meningkatkan produktivitas peternakan sapi Bali di kawasan sentra bibit sapi Bali Kabupaten Konawe Selatan, maka perlu dilakukan seleksi dan tatalaksana pemeliharaan ternak bibit sapi Bali serta pengembangan teknologi pakan guna meningkatkan kualitas pakan yang diberikan pada ternak sapi Bali yang telah diusahakan oleh masyarakat setempat, sehingga usaha peternakan ini dapat menjadi salah satu sumber pendapatan rumahtangga peternak melalui usaha ternak yang terintergasi dengan usaha pertanian.

\section{UCAPAN TERIMAKASIH}

Ucapan terima kasih kepada LPPM Universitas Halu Ole, Aparat Pemerintah Desa Wonua Morini Kecamatan Palangga atas kerjasamanya sehingga kegiatan pengabdian ini dapat terlaksana dengan baik. 


\section{DAFTAR PUSTAKA}

Abadi M, Ld. Saidi, R. Aka, Ld. Nafiu, R. Badaruddin, H. Has, H.A. Hadini, A. Indi, PNK Prasanjaya. 2019. Pemberdayaan Kelompok Tani-Ternak Dalam Meningkatkan Pendapatan Peternak Ayam Bangkok Di Desa Sindangkasih Kecamatan Ranomeeto Barat Kabupaten Konawe Selatan. Jurnal Pengamas, Vol. 02, No.2:133-143

Abdullah, A. 2008. Peranan Penyuluhan dan Kelompok Tani Ternak untuk Meningkatkan Adopsi Teknologi dalam Peternakan Sapi Potong. Dalam Prosiding Seminar Nasional Sapi Potong Palu, 24 November 2008: 188-195

Allaily, N. Ramli dan R. Ridwan. 2011. Kualitas silase ransum komplit berbahan baku pakan lokal. Agripet 11(2): 35-40.

BPS Kabupaten Konawe Selatan. 2018. Kabupaten Konawe Selatan dalam Angka 2018. Badan Pusat Statistik Kabupaten Konawe Selatan.

BPS Provinsi Sulawesi Tenggara. 2018. Sulawesi Tenggara dalam Angka 2018. Badan Pusat Statistik Provinsi Sulawesi Tenggara, Kendari.

Budiasa. 2005. Hijauan Makanan Ternak. Institut Pertanian Bogor, Bogor.

Direktorat Jenderal Peternakan. 2010. Peta Wilayah Sumber Bibit Sapi Potong Lokal di Indonesia. Direktorat Jenderal Peternakan, Kementerian Pertanian.

Diwyanto, K., L. Praharani. 2010. Reproduction management and breeding strategies to improve productivity and quality of cattle. Proc: Conservation and Improvement of World Indigenous Cattle. Study Center for Bali Cattle. Udayana University. pp. 189- 208.

Hapsari Y.T., W. Suryapratama, N. Hidayat., E. Susanti. 2014. Pengaruh lama pemeraman terhadap kandungan lemak kasar dan serat kasar silase complete feed limbah rami. Jurnal Ilmiah Peternakan 2(1): 102-109.

Hardjosubroto, W. 2004. Alternatif kebijakan pengelolaan berkelanjutan sumber daya genetik sapi potong lokal dalam sistem perbibitan ternak nasional. Wartazoa 14(3): 93-97.

Herlinae. 2003. Evaluasi nilai nutrisi dan potensi hijauan asli lahan gambut pedalaman di Kalimantan Tengah sebagai pakan ternak [Tesis]. Bogor (ID): Sekolah Pascasarjana, Institut Pertanian Bogor.

Kementrian Pertanian, 2016. Surat Keputusan Menteri Pertanian (Kepmentan) Nomor 803/kpts/PK. 030/12/2016. Kementrian Pertanian. 
Kiat LJ. 2006. Preparation and characterization of carboxymethyl sago waste and its hydrogel [tesis]. Malaysia: Universiti Putra Malaysia

Muslim. 2006. Panduan Lengkap Sapi Potong. Penebar Swadaya, Jakarta

Nafiu, L.O., T. Saili, M. Abadi, H. Has, R. Badaruddin dan F. Nasiu. 2018. Strategi Percepatan Pengembangan Kawasan Sentra Perbibitan Sapi Bali di Kabupaten Konawe Selatan, Laporan Penelitian. Kerjasama BALITBANG Konawe Selatan dengan LPPM-UHO. Kendari.

Nafiu, L.O., T. Saili, A.S. Aku, H. Has, Y. Yaddi, M. Abadi., J.K. Rahim. 2017a. Penyusunan SID Padang Penggembalaan di Kabupaten Konawe Selatan. Kerjasama Dinas Peternakan dan Kesehatan Hewan Konawe Selatan dan LPPM UHO.

Nafiu, L.O., T. Saili, A.S. Aku, H. Has, Y. Yaddi, M. Abadi., J.K. Rahim. 2017b. Penyusunan Rencana Induk Pengembangan Perbibitan Sapi Bali di Kabupaten Konawe Selatan. Kerjasama Dinas Peternakan dan Kesehatan Hewan Konawe Selatan dan LPPM UHO.

Nafiu, L.O. 2018. Pembibitan Sapi Bali di Sulawesi Tenggara: Permasalahan dan Strategi Pengembangannya. Dalam Prosiding Seminar Nasional Inovasi Teknologi Peternakan dalam Mendukung Terwujudnya Ketahanan Pangan Nasional, Kendari, 17 November 2018:17-38.

Prawiradiputra, B. P. Sajimin, Nurhayati, D.P dan Iwam H. 2006. Hijauan Pakan Ternak di Indonesia. Badan Penelitian dan Pengembangan Pertanian. Departemen Pertanian. Bogor.

Rasali H. Matondang Dan S. Rusdiana 2014 Langkah-Langkah Strategis Dalam Mencapai Swasembada Daging Sapi/Kerbau. Vol. 32 No. 3 September 2013: 131-13.

Rukmana, H. Rahmat. 2001. Silase dan Permen Ternak Ruminansia. Yogyakarta: Kanisius.

Yulianto, P. dan C. Suprianto. 2010. Pembesaran Sapi potong Secara Intensif. Penerbit Swadaya. Jakarta 